\title{
Morphology of the Pancreas in the European Bison
}

\author{
Stanisław PYTEL \& Maria WOJNOWSKA
}

Pytel S. \& Wojnowska M., 1980: Morphology of the pancreas in the Europe $n$ bison. Acta theriol., 25, 13: 141-150 [With 3 Tables \& Plates VI-VII].

Examination was made of the shape and dimensions of the pancreas in toto. In respect of shape, dimensions, weight and position the bison 5 o) from 3 days to 24 years old, and of its position in 8 bison fixed in toto. In respect of shape, dimensions, weight and position the bison pancreas is similar to that of domestic cattle. The stronger development than in cattle of the left lobe of the bison pancreas given it its characteristic axehead shape. Only the accessory pancreatic duct was found to be present in all the pancreases. The part extending beyond the gland in adult animals is from $4.5-6 \mathrm{~cm}$ in length, with a diameter of $5-11 \mathrm{~mm}$. The average total length of the fixed pancreas in adult European bison is $413 \mathrm{~mm}$ in males and $363 \mathrm{~mm}$ in females. The fresh weight of the organ in adult males is $441.5 \mathrm{~g}$, forming $0.09 \%$ of the body weight. The absolute weight of the pancreas in adult European bison and domestic cattle hybrids in $F_{1}$ males and first backcross generation males $\left(\mathrm{B}_{1}\right)$ is greater than in cattle and bison; but is smaller in relation to body weight.

[Inst. Anim. Physiol., Agric. Acad., 02-766 Warszawa, ul. Nowoursynowska 166].

\section{INTRODUCTION}

The only mention found in available literature relating to the pancreas in European bison reads: "The pancreas lies below the liver, with its larger end across the last dorsal vertebra, and its narrow prolongation accompanying the duodenum: the duct terminates in that intestine about eight inches beyond the billary inlet" ( $O$ w e $n, 1848$ ). The paper by Pytel (1969) contains a description of the major duodenal papilla and opening of the accessory pancreatic duct, while We grzyn (1978) describes, inter alia, the pancreatic veins of this animal.

In view of the exceptionally scanty data in literature, an attempt has been made in the present paper to describe the morphology and topography of the bison pancreas on the basis of material which, on account of its unique character, may be considered fairly abundant. 


\section{MATERIAL AND METHODS}

Observations of the pancreas and efferent ducts of pancreatic juice were made on a total of 24 bison (19 males and 5 females) from 3 days to 24 years old. Examination of the position of the organ was made on carcasses of 8 bison fixed in toto by intraarterial injection of the fixing media after $\mathrm{Pilarski}$ et al. (1967). Linear measurements of the pancreas were made using a transparent ruler with accuracy to $1 \mathrm{~mm}$ and referred to fixed organs. The dimensions of the descriptive parts of the pancreas situated along the long axis of the animal's body were taken as their length, and the transverse ones - as the breadth. The weight of the pancreas relates only to 12 fresh organs and 10 fixed organs.

The material was obtained from bison which had either died naturally, or been killed by anaesthetics or selective shooting.

Routine macroscopic preparation was employed, accompanied by the appropriate graphic documentation. The accesssory pancreatic duct in isolated panceases was injected with liquid plaster in order to trace its course and affluents.

Data on pancreatic weight in 21 hybrids of European bison and domestic cattle (15 males and 6 females) were included in the paper. These were animals from 6 months to 9 years old and belonged to the first $\left(F_{1}\right)$ and later $\left(B_{1}, B_{2}\right)$ generations of backcross hybrids, i.e. with decreasing percentage of bison blood. More detailed data on these hybrids are to be found in papers by $\mathrm{Krasinska} \mathrm{(1969)}$ and $\mathrm{Krasińska}$ \& Pilarski (1977); the method used for their slaughter has been described by S z u l cet al. (1971).

\section{RESULTS}

\subsection{The Bison Pancreas}

\subsubsection{Shape, Dimensions and Weight}

The bison pancreas fixed in its natural position retains its individually variable shape, due to varying proportions between the three basic descriptive parts of the pancreas, i.e. lobes (right and left) and body. It is usually similar in shape to an irregular, elongated quadrangle, like the outline of an axehead (Plate VI). The short and broad left lobe is situated at an almost right angle in relation to the smallest part of the pancreas, i.e. its body. With weaker development of the left lobe compensatory enlargement of dimensions (chiefly breadth) of the right lobe is observed. This is the case, for instance, in a 15-year old male (Plate VII). The variability in shape of the left pancreatic lobe is also connected with the degree of development of its processus uncinatus (cf. Photo $1 \mathrm{~B}$ with Photo $1 \mathrm{C}$ ). The size of incisura pancreatis is also connected to some extent with the development of this process - when it is strongly developed and the anterior part of the right lobe is well defined, an incomplete state is observed, the so-called pancreatic ring. 
A case of this kind was observed in the pancreas of a 2-year old male: the parenchyma of the gland almost completely surrounds the vessels lying in incisura pancreatis and thus also the cranial mesenteric vein and cranial mesenteric artery. These vessels penetrate through the pancreas diagonally - from the bottom and back upwards and forwards. In relation to the artery the vein lies forwards and more to the right, i.e. deeper in incisura pancreatis. The portal vein trunk is formed from the junction of the cranial mesenteric vein and the splenic vein, and this trunk imprints a distinct groove on the dorsal surface of the pancreas (Photo 1B and 1C). On the cranial end of the right lobe, near incisura pancreatis, from $1-2$ (3) pancreatic-duodenal lymph nodes are con-

Table 1

Dimensions of the bison pancreas: fixed material (in $\mathrm{mm}$ ). Average (min.-max) values are given.

\begin{tabular}{cccc}
\hline Measurement & $\begin{array}{c}\text { Young bisons, } 2-3 \text { yrs } \\
\text { Males }\end{array}$ & $\begin{array}{c}\text { Adults, } 5-17 \text { yrs } \\
\text { Males }\end{array}$ & $\begin{array}{c}\text { Adults, } 17-18 \text { yrs } \\
\text { Females }\end{array}$ \\
\hline $\begin{array}{c}\text { Total length } \\
\text { Length }\end{array}$ & 4 & 5 & 2 \\
Left lobe & 327 & 413 & 363 \\
Body & $(285-402)$ & $(390-455)$ & $(355-370)$ \\
Right lobe & 76 & 80 & 100 \\
Breadth & $(65-90)$ & $(53-107)$ & $(\mathrm{n}=1)$ \\
Left lobe & 30 & $(28-70)$ & $(45-55)$ \\
Body & $229-55)$ & 276 & 218 \\
Right lobe & $(190-295)$ & $(235-325)$ & $(215-220)$ \\
Thickness & 129 & 157 & 138 \\
Left lobe & $(115-140)$ & $(140-190)$ & $(125-150)$ \\
Body & $(25-35)$ & $(37-40)$ & $(43-50)$ \\
Right lobe & $(55-72)$ & 86 & $(80-85)$ \\
& $(18-26)$ & $(70-110)$ & $(24-46)$ \\
& $(16-42)$ & $(20-46)$ & $(18-21)$ \\
\hline
\end{tabular}

stantly observed. They usually attain considerable dimensions, e.g. in a 17-year old male one of them measured: $5 \times 2 \times 1.5 \mathrm{~cm}$, and the other $5 \times 2.5 \times 0.8 \mathrm{~cm}$.

The thin and flat caudal end of the right pancreatic lobe is distinguished by the greatest variability: it may be a whole (Photo 2) or divide in the form of a fish caudal fin (Photo 1C) or branch in the form of fingers into an individually varying number of bands (Photo 1B). 
The unfixed bison pancreas is brownish-pink in colour, the intensity of the colour depending on the degree of bleeding from the carcass and the degree to which the organ is invested by fat tissue. It is thus lighter in colour in fat animals, i.e. in adult and old females, the left lobe usually being subject to greater "fattiness " than the remainder of the pancreas. The sagittal dimension of the fixed pancreas, which is the entire length of the organ, was on an average $413 \mathrm{~mm}$ (males) and $363 \mathrm{~mm}$ (females) in adult bison (Table 1). The transverse dimension of the pancreas exhibits maximum values for the measurement defined as breadth of left lobe, reaching an average value of $157 \mathrm{~mm}$ in males and $138 \mathrm{~mm}$ in females. The thickness of the pancreas is far less than the preceding values and is greatest in the body (males) or anterior part of the right lobe (females).

The weight of the unfixed pancreas in male bison increases with age In absolute values, but in relation to body weight is the same in an 6 -month old calf as it is in a 5 -year old bull (Table 2). The weight of the fixed pancreas in adult males is slightly less than that of unfixed organs.

\subsubsection{Accessory Pancreatic Duct}

In all the bison pancreases examined only one efferent duct, i.e. the uccessory pancreatic duct, was observed. It begins in the area of the left lobe, which it soon leaves and runs towards the body, bending at an almost right angle (Plate VII). Its course continues hidden in the pancreatic parenchyma in the area of the right lobe, and receives a small number of lateral affluents. It is accompanied in this place by lymphatic and blood vessels, the greatest of which is the vein termed in the European bison vena pancreatica magna (W ęg rzy $\mathrm{n}, 1978$ ). The lumen of the vein becomes smaller in a direction towards the posterior of the right pancreatic lobe, but the diameter of the accessory pancreatic duct increases. The lumen of its terminal part varies in young bison from 4 to $7 \mathrm{~mm}$ (average $5 \mathrm{~mm}$ ) and in adult bison - 5-11 $\mathrm{mm}$ (average $7.7 \mathrm{~mm}$ ). It was only in one case (a 15-year old male) that this duct was $21 \mathrm{~mm}$ in diameter: this phenomenon was accompanied by an unusual way of opening into the duodenum ( $\mathrm{P}$ y $\mathrm{t}$ el, 1969). The length of the part of the duct lying outside the boundary of the gland was from 4.5 to $6 \mathrm{~cm}$. The place in which the accessory pancreatic duct contacts the duodenal wall is situated at the level of the lumbar transverse process of the second or third (fourth) lumbar vertebra, but 10-17 $\mathrm{cm}$ lower (Photo. 4). This place is situated about $5 \mathrm{~cm}$ towards the rear from the posterior margin of the final (XIV) rib. Forwards from the 
place of contact of the duct with the intestine the descending duodenum. forms a characteristic loop.

\subsubsection{Position of the Pancreas}

The bison pancreas lies completely in the right half of the abdominal cavity. The long axis of the organ is situated diagonally to the horizontal plane, i.e. from the front and bottom backwards and upwards. The left lobe protrudes furthest forward, since it reaches the 12 intercostal space or 13 thoracic vertebra. The posterior end of the right lobe defines the caudad reach of the pancreas - it lies at the level of the $3-4 / 5$ lumbar vertebra.

The left border of the left pancreatic lobe is situated closest to the sagittal median plane. It reaches to the visceral surface of the dorsal sac of the rumen and is directed upwards, between the descending colon (from the right side) and the intestinal surface of the dorsal end of the spleen, slightly to the rear of its hilus (from the left side). The impression of the descending colon and of the anterior part of the suprarenal gland (Photo. 1A) can be seen on the ventral surface of the left lobe.

The posterior end of the right pancreatic lobe is situated furthest. from the sagittal plane referred to, that is, most laterally. It can be seen after cutting through the soft abdominal wall in the right paralumbar fossa, backwards and downwards from the right kidney (Photo. 4). Hereit lies on gyrus dorsalis of the distal loop of the colon. The impression of the gyrus medius of the proximal loop of the colon can be seen in the median part of the right pancreatic lobe and consequently this part. of the pancreas takes the form in cross-sections of a triangle with zoncave sides (corresponding to the convexity of the organs surrounding it - the right kidney and colon loops).

The dorsal surface of the pancreas body adheres to the caudate process: of the liver and its right lobe. The ventral surface of the body lies on gyrus ventralis of the distal loop of the colon and on the transverse colon. The part of the duodenum lying immediately after the opening. into it of the bile duct adheres to the right border of the pancreas.

\subsection{Weight of the Pancreas in European bison and Domestic Cattle Hybrids}

The absolute weight of a fresh pancreas in hybrids is greater in males than in females, whereas the reverse is the case in respect of relative weight (Table 3). This applies to all age groups in the generations compared.

Since groups of different age were available only among males 10 - Acta Theriologica 
of the backcross generation, with increasing age gradual increase in the absolute weight of the pancreas was observed here, with simultaneous decrease in its relative weight. The average values for absolute weight of the pancreas in $\mathrm{F}_{1}$ males are only $2.9 \%$ higher than in $\mathrm{B}_{1}$.

Table 2

Body weight and absolute and relative weight of the bison pancreas. 1 Without conservation, 2 After conservation.

\begin{tabular}{|c|c|c|c|c|c|}
\hline Group/age, years & $\mathrm{n}$ & Body wt., kg & Absolute, $\mathbf{g}^{1}$ & Relative, $\% 1$ & Absolute, $\mathrm{g}^{2}$ \\
\hline \multicolumn{6}{|c|}{ Males } \\
\hline Calves, 0.5 & 1 & 110 & 98.7 & 0.09 & - \\
\hline Young bisons, $1.5-2$ & 4 & $\begin{array}{l}189(\mathrm{n}=3) \\
(190-206)\end{array}$ & $\begin{array}{c}197.0 \\
(115.7-270.0)\end{array}$ & $\begin{array}{c}0.09 \quad(n=3) \\
(0.06-0.13)\end{array}$ & 一 \\
\hline Young bisons, $3-4.5$ & 2 & - & - & $1-$ & $\begin{array}{c}227.0 \\
(200.5-253.3)\end{array}$ \\
\hline Adults, $5-17$ & 6 & $500(n=1)$ & $\begin{array}{c}441.5(n=4) \\
(350.0-550.0)\end{array}$ & $0.09(\mathrm{n}=1)$ & $\begin{array}{c}428.2 \\
(321.2-550.0)\end{array}$ \\
\hline \multicolumn{6}{|c|}{ Females } \\
\hline Calves, 0.5 & 2 & $107(n=1)$ & 88.0 & $0.07(n=1)$ & - \\
\hline Young bisons, 1.5 & 1 & 170 & 102.5 & 0.06 & - \\
\hline Adults, $17-18$ & 2 & - & - & - & $\begin{array}{c}309.5 \\
(297.0-322.0)\end{array}$ \\
\hline
\end{tabular}

Table 3

Body weight and absolute and relative pancreas weight ( $($ SD) in hybrids of European bison and domestic cattle (material before conservation).

\begin{tabular}{lrrrr}
\hline \multicolumn{1}{c}{ Group/age, years } & $\mathrm{n}$ & Body wt., kg & Absolute, $\mathrm{g}$ & Relative, $\%$ \\
\cline { 5 - 5 } & & & Males \\
Hybrids $\mathrm{F}_{1}, 5-8$ & 3 & $913.7 \pm 90.5$ & $605.0 \pm 122.6$ & $0.07(0.05-0.07)$ \\
Hybrids $\mathrm{B}_{1}, 3.5-5.5$ & 7 & $578.1 \pm 52.0$ & $587.6 \pm 73.7$ & $0.10(0.08-0.12)$ \\
Hybrids $\mathrm{B}_{1}, 1.5-2.5$ & 3 & $473.3 \pm 83.3$ & $435.0(\mathrm{n}=1)$ & $0.11(\mathrm{n}=1)$ \\
Hybrids $\mathrm{B}_{1}, 0.5$ & 2 & $274.5 \pm 16.3$ & $332.5 \pm 24.8$ & $0.12(0.11-0.13)$ \\
& & Females & & \\
Hybrids $\mathrm{F}_{1}, 7-9$ & 2 & $511.0 \pm 29.7$ & $587.5 \pm 81.3$ & $0.11(0.11-0.12)$ \\
Hybrids $\mathrm{B}_{1}, 1-2.5$ & 3 & $297.7 \pm 28.1$ & $390.0 \pm 17.3$ & $0.13(0.12-0.14)$ \\
Hybrids $\mathrm{B}_{2}$ & 1 & 429.0 & 500.0 & 0.12 \\
\hline
\end{tabular}

$F_{1}-$ hybrids first generation; $B_{1}$-backcross hybrids: $1 / 4$ bison $3 / 4$ cattle; $B_{2}-$ backcross hybrids $1 / 8$ bison $7 / 8$ cattle.

\section{DISCUSSION}

The bison pancreas is similar in general outline to the description of the pancreas in domestic cattle ( $\mathrm{Z}$ e d e nov, 1965). It would, however, appear that in European bison the left lobe of the pancreas is larger and situated more vertically to the long axis of the gland than in cattle, 
in which the right lobe of the pancreas is broader. These observations, however, were not made on the basis of numerical data, since it proved impossible to find dimensions of the descriptive parts of cattle pancreas in literature. Only the following data are usually given: approx. $45 \mathrm{~cm}$ in length and $11 \mathrm{~cm}$ in breadth (M a r t in \& $\mathrm{S} \mathrm{ch}$ a u der, 1938).

J u rk ov (1948), who found processes running from the right lobe in $12.8 \%$ of his cases, drew attention to the great degree of variation in the shape of the pancreas in cattle. The variable end of this lobe in the bison pancreas makes it similar to the buffalo pancreas, which was forked in $40 \%$ of the cases ( $\mathrm{M} \mathrm{a} \mathrm{r} \mathrm{t} \mathrm{ir} \mathrm{o} \mathrm{s} \mathrm{j} \mathrm{a} \mathrm{n}, 1953)$. The occurrence in European bison of a pancreas forming an incomplete ring round the cranial mesenteric vein and artery has connections with the pancreatic ring observed in $5.3 \%$ of domestic cattle and its absence in Zebu cattle (S a n tis Prada \& H ig a shi, 1966-67).

The pancreas in adult bison is similar to that of domestic cattle both in respect of absolute and relative weight ( $\mathrm{Martin} \& \mathrm{Sch}$ a u der, 1938; N ickel et al., 1960; S is s o n \& Gross ma n, 1960; ž ed e nov, 1965). The failure to find a decrease with age in relative weight of the pancreas in European bison, although this is known to occur in domestic cattle (A u erheimer, 1910), may be due to the small number of the author's observations.

The absolute weight of the pancreas in hybrids of European bison and domestic cattle in generations $\mathrm{F}_{1}$ and $\mathrm{B}_{1}$ (particularly in males) is greater than in the two initial forms. In this case also the phenomenon of heterosis, shown earlier to occur in the case of other internal organs of these hybrids, makes its appearance (P y tel \& K rasińs ka, 1971; Pytel et al., 1977; Krasińska \& Pilarski, 1977). Probably on account of the lesser differences in weights of the pancreas in European bison and domestic cattle this is less evident here. The comparatively small relative weight of the pancreas in male $F_{1}$ hybrids (lower than the average values for bison and cattle, and also for $\mathrm{B}_{1}$ males) may be due to the great body weight of these animals (average weight $-914 \mathrm{~kg}$ ).

As early as 1848 Owen found only one efferent duct in the bison pancreas and the case is similar in respect of the buffalo (M a r tir o s$\mathrm{j}$ a $\mathrm{n}, 1953)$. In cattle, however, two ducts have been shown to occur in $17.2 \%$ of the cases examined, i.e. the pancreatic duct and accessory pancreatic duct (J urkov, 1949, cited after ž edenov, 1965). The pancreatic duct in such cases opens by the side of, or oposite $(4.7 \%$ of cases) the bile duct. W a s s (1956) showed by means of experiments that two ducts occurred in the majority of the cattle be examined. In zebu cattle also anastomoses (the remainder of the pancreatic duct) 
were found in $41 \%$ of the cases, between the accessory duct and the bile duct (S a n t is Prada et al., 1966).

Acknowledgements: Our sincere thanks are due to Professor Zdzisław Pucek, Head of the Mammals Research Institute, Polish Academy of Sciences, at Białowieża and to Dr. Małgorzata Krasińska, for placing at our disposal material of European bison and cattle hybrids and for their unfailing assistance during these studies and preparation for publication.

\section{REFERENCES}

1. A uernheimer O., 1910: Grossen- und Formveränderung der Baucheingeweide der Wiederkäuer nach Geburt bis zum erwachsenen Zustand. Z. Fleisch- und Milchhyg., 20: 393-396.

2. J u rk ov M. I., 1940: Morfologia podželudoěnoj železy i jejo protokov u krupnogo rogatogo skota $\mathrm{v}$ sravnitelno-anatomičeskom osvešcénii. Diss. (Cited after Żedenov V. N., 1965).

3. J u rk ov M. I., 1948: Variacii formy podželudočnoj železy u krupnogo rogatogo skota. Tez. dokl. nauč. metod. konf. anat. gistol. i embriol. zoovet. i s/h vuzov. Moskva.

4. $\mathrm{Kr}$ a sińsk a M., 1969: The postnatal development of $F_{1}$ hybrids of European bison and domestic cattle. Acta theriol., 14, 7: 69-117.

5. Krasińska M. \& Pilarski W., 1977: Biometric analysis of some internal organs of hybrids between the European bison and domestic cattle. Acta theriol., 22, 6: 121-139.

6. Martin P. \& S S hauder W., 1938: Lehrbuch der Anatomie der Haustiere. 3: 213-214, Schickhardt \& Ebner. Stuttgart.

7. Martirosjan A. T., 1953: Morfoloričeskie osobennosti glavnyh piščevaritelnyh želez bujvola. Tr. Erev. Zoovet. Inst., 15: 135-141.

8. Nickel R., Schummer A. \& Seiferle E., 1973: The viscera of the domestic mammals. P. Parey: 179-180. Berlin-Hamburg.

9. O we n F., 1848: Notes on the anatomy of the male aurochses (Bison europeus L.). Proc. zool. Soc. London, 16: 126-133.

10. Pilarski W., Serwatka S., Swieżyński K. \& Węgrzyn M., 1967: New attempts at fixing anatomical material of large mammals. Acta theriol., 12, 31: $453-458$.

11. Pytel S., 1969: Morphology of digestive tract of the European bison. Acta theriol., 14, 27: 349-402.

12. Pytel S. \& Krasins a M., 1971: Morphology of the stomach and intestines in the European bison and its hybrids with domestic cattle. Acta theriol., 22, 481.

13. Pytel S. \& W ęgrzy n M., 1976: Morphology of the liver of European bison. Acta theriol., 21, 2: 19-30.

14. Pytel S., Krasińska M. \& Węgrzyn M., 1977: Morphology of the spleen in the European bison and its hybrids with domestic cattle. Acta theriol., 22, 7: $141-149$.

15. Santis Prada I. L. de, Borelli V. \& Higashi H., 1966: Contribuicao ao estudo do sistema excreator do pancreas em bovinos azebuados. Arq. Inst. Biol., 33, 4: 125-135. 
16. Santis Prada I. L. de, \& Higashi H., 1966-1967: Sobre a ocorrencia de anel pancreatico em bovinos. Rev. Fac. Med. Vet. S. Paulo, 7, 3: 535-540.

17. Sisson S. \& Grossman J., 1960: The anatomy of the domestic animals. W. B. Saunders Co.: 475-477, Philadelphia-London.

18. Szulc M., Tropiło J. \& Krasińska M., 1974: Dressing percentage and utility value of the meat of European bison and domestic cattle hybrids. Acta theriol., 16, 32: 438-504.

19. Was s W. M., 1965: The duct system of the bovine and porcine pancreas. Amer. J. Vet. Res., 26, 111: 267-272.

20. W ę g r z y n M., 1978: Układ naczyniowy żylny żubra Bison bonasus (Linnaeus, 1758). Zesz. Nauk. SGGW-AR w Warszawie. Rozprawy naukowe, 108: 1-107.

21. Ž e de nov V. N., 1965: Anatomia domašnich životnyh. 2: 167-175, Vys. Škola, Moskva.

Accepted, 21 September, 1979.

\section{Stanisław PYTEL i Maria WOJNOWSKA}

\section{MORFOLOGIA TRZUSTKI ZUUBRA}

\section{Streszczenie}

Zbadano kształt i rozmiary trzustki u 24 żubrów (19 $\sigma^{*}$ i 5 \% $)$ w wieku od 3 dni do 24 lat; określono ciężar 12 trzustek świeżych i 10 utrwalonych. Opisano położenie trzustki u 8 żubrów utrwalonych in toto.

Pod względem kształtu, wymiarów, ciężaru i polożenia trzustka żubra podobna jest do trzustki bydła domowego, ale silniejszy rozwój płata lewego nadaje jej charakterystyczny kształt topora (Fot. 1). We wszystkich badanych trzustkach stwierdzono obecność jedynie przewodu trzustkowego dodatkowego (Fot. 2-4).

Długość całkowita utrwalonej trzustki dorosłych żubrów wynosi średnio $413 \mathrm{~mm}$ u samców i $363 \mathrm{~mm}$ u samic (Tabela 1); ciężar świeżej trzustki osiąga średnio $441.5 \mathrm{~g}$ u dorosłych samców, co stanowi $0.09 \%$ ciężaru ciała (Tabela 2).

Bezwzględny ciężar trzustki dorosłych mieszańców żubra z bydłem domowym u samców $F_{1} i$ pierwszego pokolenia wstecznego $\left(B_{1}\right)$ jest większy niż u bydła i żubra; w stosunku do ciężaru. ciała jestion mniejszy (Tabela 3).

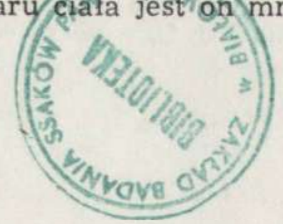




\section{EXPLANATION OF PLATES}

\section{Plate VI}

Phot. 1. Bison pancreas, A) ventral surface ( $\sigma^{\star}$, Pokorny, 9 years old), B) dorisal surface ( $\sigma^{\star}$, Puniter, $9^{1} / 2$ years old), C) dorsal surface $\left(\sigma^{\star}\right.$ Karpacz, 17 years olld).

\section{Plate VII}

Phot. 2. Bison pancreas ( $\sigma^{*}$, Pomruk, 15 years old) with its accompanying vessiels and lymph nodes, A) ventral surface, B) dorsal surface.

Phot. 3. Bison pancreas ( $\sigma^{x}$, Pomruk, 15 years old) with open accessory pancreatic duct (1).

Phot. 4. Position of the pancreas in bison ( $\sigma^{x}$, Puniter, $91 / 2$ years old) seen from right side:

a - left lobe, a'-processus uncrnatus, a" -impression of portal vein, b-body, c-right lobe, d-incisura pancreatis, cr-cranial mesenteric vein, pr-portal vein, ca - cranial mesenteric artery, w - pancreatic duodenal lymph nodes, 1 accessory pancreatic duct, 2 - right kidney, 3 - descending colon, 4 - final (XIV) rib, 5 - third lumbar transverse process. 

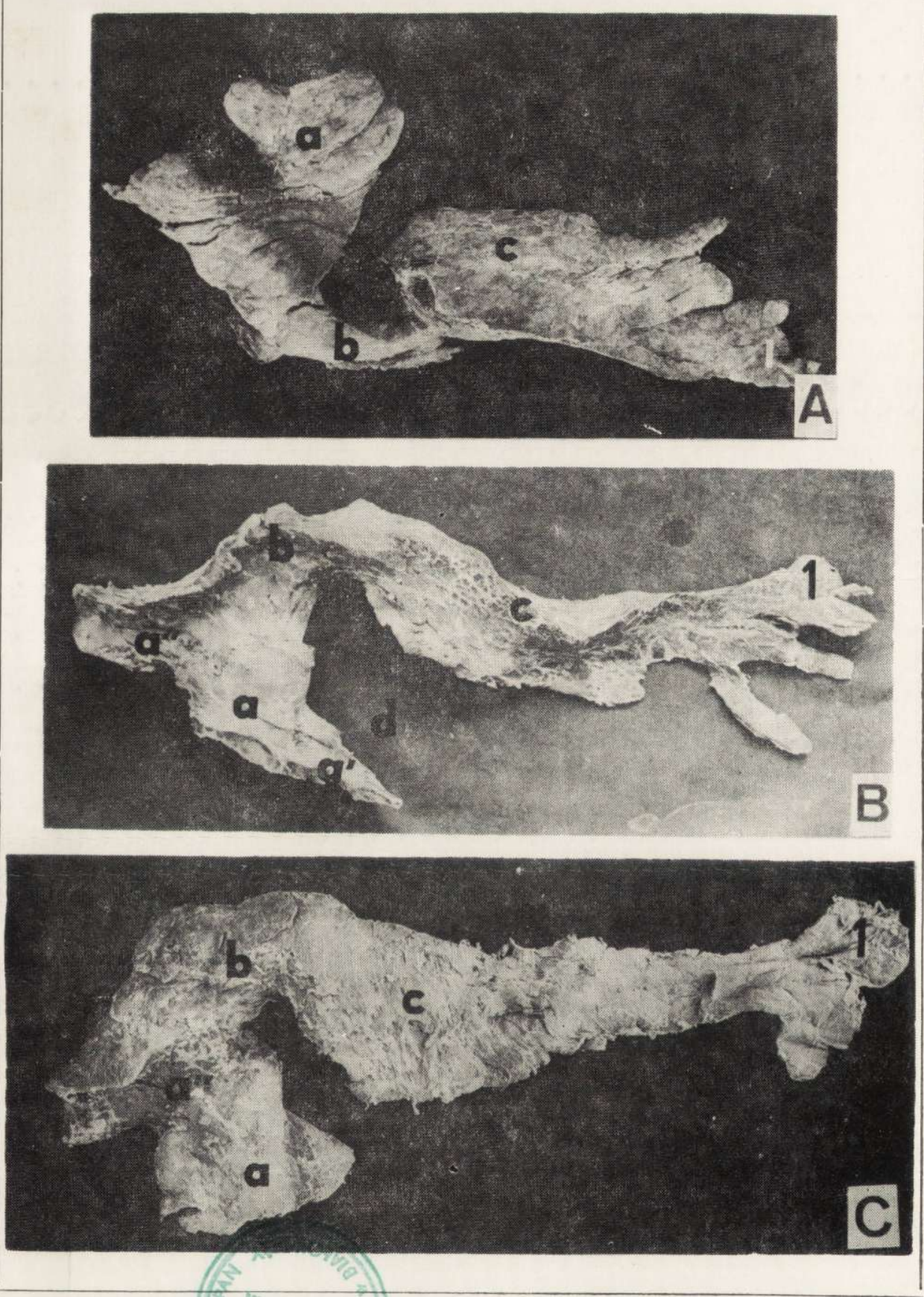

S. Pytel \& M. Wojnowska 
ACTA THERIOLOGICA, XXV, 13

Plate VII.

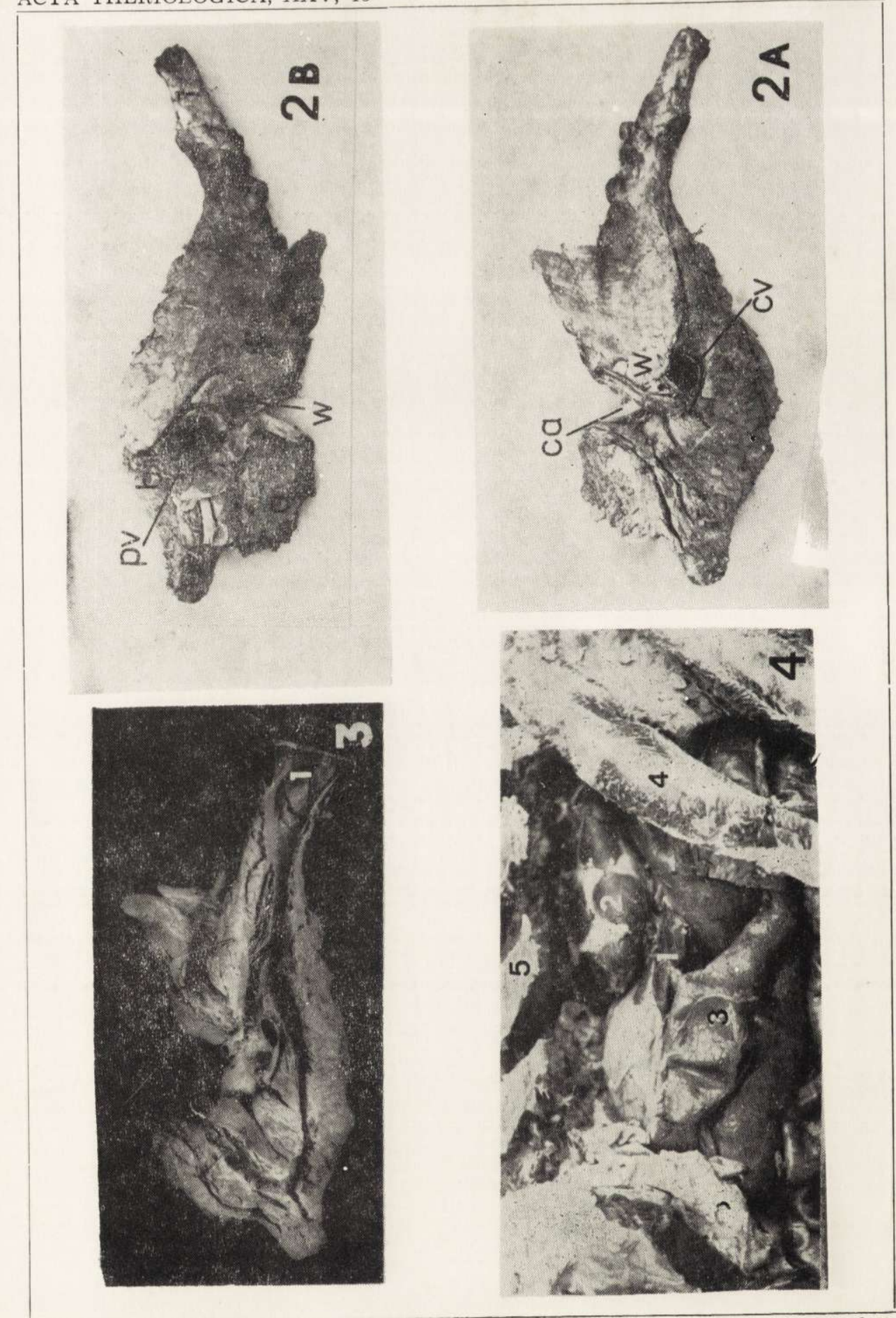

S. Pytel \& M. Wojnowska

Auctores phot. 